\title{
Energy Analysis of Concentrated Photovoltaic/Thermal Panels with Nanofluids
}

\author{
Hakan Dumrul $^{1 *}$, Sezayi Y1lmaz ${ }^{1}$, Metin Kaya ${ }^{1}$, İlhan Ceylan ${ }^{1}$ \\ ${ }^{1}$ Department of Energy Systems Engineering, Technology Faculty, Karabuk University, Karabuk, Turkey \\ *Corresponding Author Email: hakandumrul@karabuk.edu.tr
}

Received 18 February 2021, Revised 30 March 2021, Accepted 23 April 2021

\begin{abstract}
In this study, a prototype system was established for location heating application and electricity generation through utilizing two concentrated photovoltaic thermal panels (CPV/T) possessing flat surface receivers connected in series with each other. The purpose of the system is to supply the heating needs of a room in winter season and to meet the electricity requirement of the equipment used in this system. In the analysis of the installed system, different refrigerants $\left(10 \%\right.$ mono propylene glycol $+90 \%$ water and $0.5 \% \mathrm{Al}_{2} \mathrm{O}_{3}$-water nanofluid) were tested at three different flow rates $\left(0.4 \mathrm{~m}^{3} / \mathrm{h}, 0.5 \mathrm{~m}^{3} / \mathrm{h}, 0.6 \mathrm{~m}^{3} / \mathrm{h}\right)$. Throughout the experiments, the fan-coil air outlet temperature used to heat the room was adjusted to $35^{\circ} \mathrm{C}$ with an inverter and a process control device. The results attained from the experiments carried out using different fluids throughout different months and days (April-May) have demonstrated that the thermal and electrical efficiencies of the system are found to be in good agreement with each other when evaluated in terms of the fluids utilized. The highest electrical energy recovery was found as $268 \mathrm{~W}$ at $0.6 \mathrm{~m}^{3} / \mathrm{h}$ flow rate for propylene glycol-water mixture and $194 \mathrm{~W}$ at $0.5 \mathrm{~m}^{3} / \mathrm{h}$ flow rate for nanomixture. The total thermal energy efficiency for the system using different fluids was found to be around $22 \%$. The total thermal energy gain of the system was also calculated as $2312 \mathrm{~W}$ at $0.6 \mathrm{~m}^{3} / \mathrm{h}$ for the propylene glycol mixture and $2041 \mathrm{~W}$ at $0.5 \mathrm{~m}^{3} / \mathrm{h}$ for the nanomixture.
\end{abstract}

Keywords: Concentrated PV/T; solar energy; heating; coolant; energy analysis.

\section{Introduction}

Solar energy is widely regarded as one of the crucial energy sources for the upcoming years due to being environmentally friendly and its massive contribution to lots of technological applications in our daily life. Since solar energy does not release any hazardous materials to atmosphere and does not cause any contamination on earth, it can be employed in the any technological development required to get rid of those drawbacks of the conventional fossil fuels. In the sense of above-mentioned facts, Photovoltaic (PV) technology has drawn considerable great deal of interest owing to the fact that it directly transforms solar radiation into environmentally friendly energy, consequently, possesses positive effects on human life by making our life more comfortable and affordable. PV systems take up the 50 percent of the solar radiation as thermal energy, whose $15 \%$ is interchanged into the electrical energy. However, this thermal energy is known to bring about substantial decrease in the efficiency by disrupting module structure. This temperature increase causes panels' electrical efficiency to decrease; this decrease is $1-2 \%$ at temperatures above $30{ }^{\circ} \mathrm{C}$. For this reason, many studies focusing on the increase the PV performance have been conducted on photovoltaic thermal panels (PV/T). $\mathrm{PV} / \mathrm{T}$ is the best systematic method to increase the efficiency of the photovoltaic panel. A PV/T panel increases the usage area of solar energy, providing both electricity and heat energy [1-3]. The fundamental method in the studies on $\mathrm{PV} / \mathrm{T}$ or $\mathrm{CPV} / \mathrm{T}$ technologies is the cooling of $\mathrm{PV}$ surfaces. In these studies, different cooling techniques are used, some of which are the use of heat pipes, thermo-electric devices, phase change materials on the back surface; by passing air or fluids from the back surface of the panel. The heat removed in this way can be used for heating applications using different systems in industrial and residential areas. There are many PV/T or CPV/T systems, according to the type of cooling and one of the most common is fluid cooled. To absorb heat from these systems in the best way, researchers have benefited from nanofluids [4-8]. The studies involving these systems and the fluids used to remove heat in these systems are reviewed below. Youssef et al. have developed a numerical model for energy and economic performance evaluation in a concentrated photovoltaic/thermal collector using nanofluid (water $+\mathrm{Cu}$ ) under the climatic circumstances of Tunisia and Chambery provinces and fulfilled the experimental analysis of the system. It was also stated that when the nanoparticle concentration in the nanofluid is increased from $0 \%$ to $0.2 \%$, the increase in thermal and electrical efficiency was found to be approximately $15 \%$ and $0.2 \%$, respectively. Finally; examining the economic efficiencies for the $\mathrm{CPV} / \mathrm{T}$ system under Tunisia and Chambery's circumstances, it was found that it was 35\% in Tunisia and 38\% in Chambery [9]. Zuhur et al. have designed and produced a concentrating photovoltaic cooling system to meet the electricity and cooling needs of the building where the system is applied. The manufactured prototype was tested with and without concentrator and obtained findings were used in the energy, exergy, and cost calculation. When evaluating the experimental performances, it could be inferred that the utilization of the concentrator does not have a significant influence on the thermal energy gain. The total energy gain for the system is also calculated as approximately $30 \mathrm{~W}$. Besides, it is addressed that the use of concentrators increases exergy efficiency. It is also noteworthy that the electrical efficiency of the panels using a concentrator is 
lower than the efficiency of the panels without a concentrator, since the temperature of the back surface increases. It is stated that efficiency is not a correct indicator in terms of energy generation for concentrating systems and electrical gain or exergy are most significant parameters of these systems. Finally, examining the system in detail in terms of the environmental cost, it is revealed that it saves approximately $0.1 \mathbb{C}$ due to the decrease in the $\mathrm{CO}_{2}$ generation [10]. Zuhur and Ceylan have designed and constructed a concentrated photovoltaic/thermal (CPV/T) air collector to make contribution to studies dealing with the construction of green buildings. It is stated that the system aims to supply the heating and electricity needs of the structure during freezing winter days. The prototype was examined with and without a concentrator and the attained findings were utilized to calculate energy, exergy, and environmental costs. The total thermal energy efficiency of systems with and without concentrator is found around 50\%. The total thermal energy gain is calculated to be $220 \mathrm{~W}$ for the system with a concentrator and $136 \mathrm{~W}$ for the system without a concentrator [11]. Alves et al. developed a partnership with the Swedish company called Solarus AB to explore the performance of a $\mathrm{CPV} / \mathrm{T}$ in different climatic zones (Sweden and Portugal), and the CPV/T produced by this company focused on the influence of thermal effects on energy efficiency. Therefore, they created the electromagnetic/thermal finite element model (SEM) of 2dimensional and 3-dimensional CPV/T to calculate the heat transfer subject to the flow of the refrigerant. Taking the fluid flow rate into account, studies conducted for Portuguese environmental conditions demonstrated that until the PV cells reach their highest operating temperatures $\left(85^{\circ} \mathrm{C}\right)$, the flow rate should be in the range of $0.5-2$ liters per minute and should never be less than 0.031 per minute [12]. Bellos and Tzivanidis carried out the simulation analysis of the concentrated photovoltaic thermal system with and without nanofluid, with a parabolic reflector, using Solidworks Flow Simulation. In their work, Syltherm 800/copper oxide $(\mathrm{CuO})$ nanofluid with $5 \%$ volumetric concentration and the basic fluid (Syltherm 800) were tested and a comparison was also made between fluids. The usage of nanofluid is reported to be useful for all cases investigated and higher thermal and electrical output is also achieved. they found that with nanofluid, thermal efficiency increase is $1.66 \%$, electrical efficiency increase is $5.17 \%$, total efficiency increase is $2.08 \%$ and exergy increase is $3.05 \%$; However, when the fluid inlet temperature was set to $100{ }^{\circ} \mathrm{C}$ and the flow rate was $540 \mathrm{~L} / \mathrm{h}$, the heat transfer coefficient increased by $27.74 \%$ with the nanofluid [13]. In their study, Koronaki and Nitsas studied 5 unsymmetrical hybrid solar collectors possessing flat surface receivers connected in series empirically and mathematical equation derived from heat transfer and thermodynamic expressions. The results of the experimental practice conducted by Koronaki and Nitsas are as follows: (1) The highest generation of useful energy was $2278 \mathrm{~W}$ and was determined almost noontime. (2) The largest exergy efficiency was observed for high temperatures. (3) Collectors are found to operate more effectively in spring and fall compared to summer. (4) Series connected solar collectors; the useful energy produced throughout a year subject to climate circumstances, for instance, they can produce approximately $2.2 \mathrm{~kW}, 2.8$ and 2.6 of useful energy in summer, spring, and autumn, respectively [14]. Sarafraz et al. designed a cooling jacket filled with MWCNT-paraffin to enhance the heat transfer rate between the panel and the refrigerant and to minimize heat loss. An experimental study was carried out to assess the electrical and thermal power generation of the $\mathrm{PV} / \mathrm{T}$ system created through placing the cooling jacket behind the panel. The multi-walled carbon nanotube-water / ethylene glycol nano fluid was passed through the pipes forming the cooling jacket in the system. From the results attained, it was stated that the existence of MWCNT - WEG50 nano fluid improves the thermal performance of the system. It was also reported that there is a $20 \%$ increase in the electrical production of the system and a $130 \%$ increase in the thermal production [15].

In this study, an efficient CPV/T heating system was designed and experimentally analyzed. The goal of the system is to generate heat for location heating applications and to meet the electricity needs of all devices used in the system. The concentration rate of the concentrated photovoltaic thermal panels used in the study is 1.4 . The heat obtained from the fluid heated across the $\mathrm{CPV} / \mathrm{T}$ panels was transferred to the room to be heated via a fan-coil (fan-air heater). In the selection of the fan-coil used in the system, we have paid attention to its capacity to transfer the heat obtained from the panels to the room. The measurements were performed at the different flow rates on cold days and influence of the fluids employed in heat transfer across the system was also examined. The collectors are placed in Turkey, Karabük province, installed at the University Campus with a tilt angle of $30^{\circ}$ and the open-circuit mode was used throughout tests for the PV modules. Transition type climate is effective in Karabük, which is in the transition area from Black Sea climate to continental climate. The annual average temperature is $13.20^{\circ} \mathrm{C}$. the coldest and the hottest month of the season are considered to be as January and July with the average temperature of $2.60^{\circ} \mathrm{C}$ and 21.10 , respectively [16]. At the same time, ambient circumstances and mass flow rate of the heat transfer fluid were bear in mind. The effect of fluids operated on the heating performance and electricity production was investigated in our work.

\section{Operating procedure}

The working principle scheme of the experimental system established in the study is as in Figure 1. The system is made up of nanofluid/PG fluid cycle, air cycle, and automation cycle combinations. In the first cycle, the pump used in the system circulates the nanofluids between the concentrated photovoltaic thermal panels and the fan-coil at fixed flow rates. The main purpose is to increase the temperature of the fluid thermally with the solar radiation falling on the CPV/T panels and to increase the electrical power of the heated CPV/T panels by cooling. In the second cycle, the ambient air is forced through a fan-coil, heated, and blown into the room. The flow rate of the air used for heating the room is adjusted with an inverter and a process control device that controls the motor speed of the fan heater. In this cycle, the temperature of the heated air was measured with a thermocouple and the outlet temperature of the fan heater was also set to $35^{\circ} \mathrm{C}$. The temperature of the heating air is observed to rise with the increase of the heat energy stored via the fluid heated by the solar radiation across the $\mathrm{CPV} / \mathrm{T}$ panels. In the automation cycle, the set temperature for the concentrated photovoltaic thermal system was determined as $35^{\circ} \mathrm{C}$ on the control equipment. In the loop, the set temperature of the control equipment and the fan-coil outlet temperature were comparatively evaluated. Here, if 
the set temperature $\left(35^{\circ} \mathrm{C}\right)$ is lower or higher than the value measured at the outlet of the fan-coil, the inverter has adjusted to keep the temperature of the heating air at the desired air outlet temperature. Thus, the temperature of the heating air was provided to be close to the set temperature.

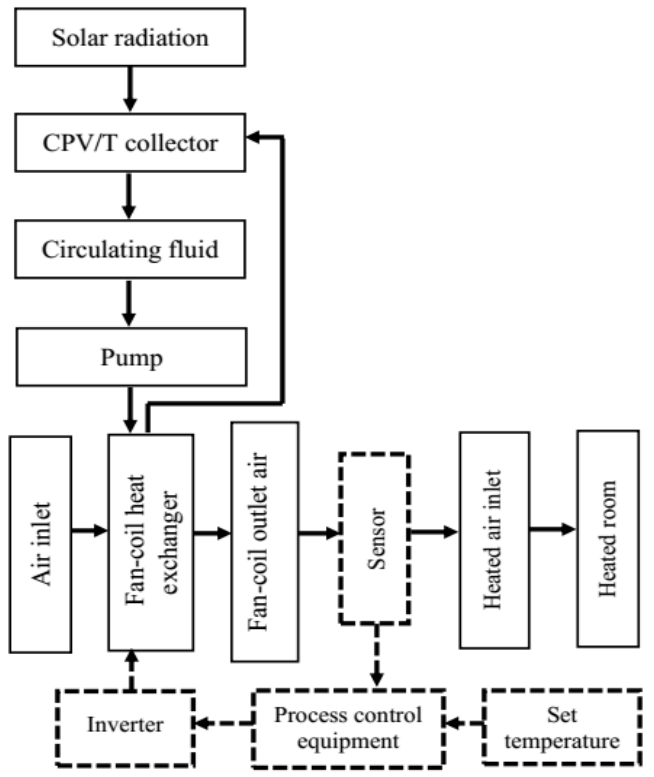

Figure 1. Flow chart of the system.

\section{Experimental analysis}

The experimental setup of the system designed for space heating application and electricity generation in cold weather is shown in Figure 2 and was examined in this research article. Prior to running the experiments, experimental system was vacuumed and the system was also filled with the appropriate heat transfer fluid, considering the capacity values of the CPV/T's capacity module $(1.4 \mathrm{~L} /$ module $)$ and other elements of the experimental system (such as, fan-coil, pipes, expansion tank, etc.).The experiments were carried out on 6 different days and the measurements were performed between 09:50 and 18:20 for each day of the experiments $(10 \%$ mono propylene glycol $+90 \%$ water was tested, on 10-13-18.04.2020 days for 3 different mass flow rate and $0.5 \% \mathrm{Al}_{2} \mathrm{O}_{3}$-water nano-fluid was also tested on 3 different days on 14-16-18.05.2020 for 3 different mass flow rate). In the testing system, Solar radiation on CPV/T panels was measured with a pyranometer connected to the data acquisition card system. The data collected on the SD card in the data acquisition card system was then transferred to the computer. The temperature of the inlet and outlet of the fancoil and the inlet and outlet of the $\mathrm{CPV} / \mathrm{T}$ panels were measured in the heated environment, and over the fan-coil, the air velocity was also determined. Fan-coil air outlet temperature was measured with Ordel PC440 controller used for controlling the motor drive inverter. The electrical energy generated by $\mathrm{CPV} / \mathrm{T}$ panels and electrical energy stored in the batteries were measured via the solar hybrid inverter. CPV/Ts' properties can be seen in Table 1. Online grid hybrid inverters' properties are given in Table 2. The most suitable fan-coil features selected for the system are given in Table 3. The measurement points in the system and specifications of measurement devices are provided in Figure 3 and Table 4, respectively. The density, heat capacity, thermal conductivity, and viscosity values of nanofluid and propylene glycol-water mix are given in Table 5. The thermal analysis of the experimental system was carried out and the electrical energy obtained from the system was analyzed.

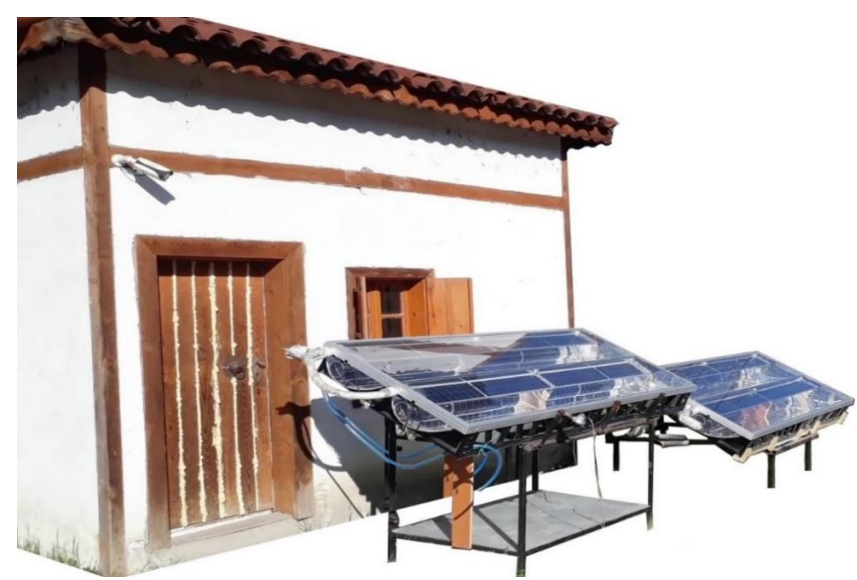

Figure 2. Experimental setup of the designed system.

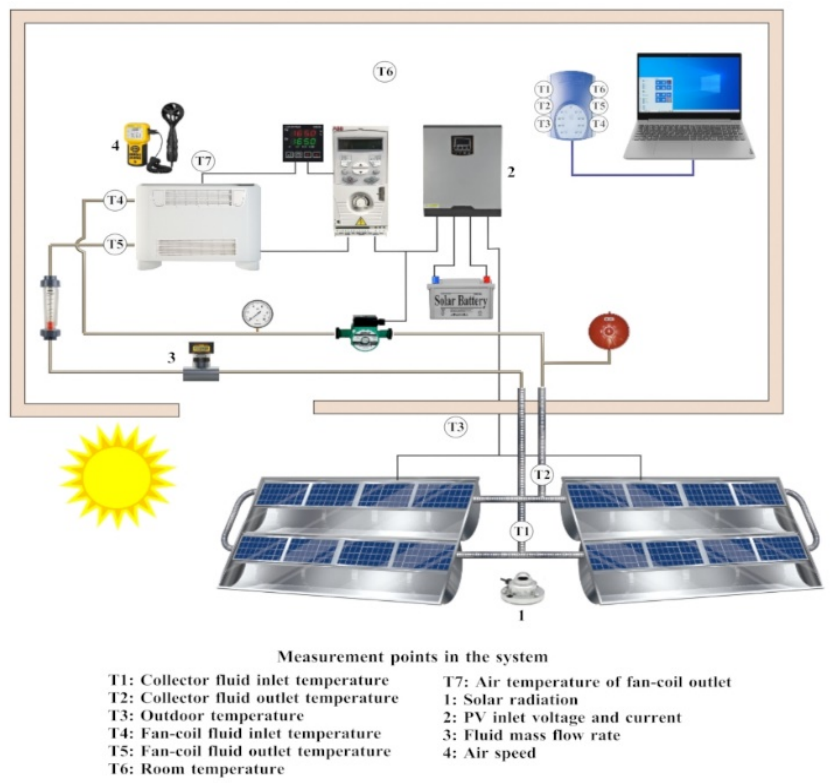

Figure 3. Schematic representation of the devices and measurement points.

Table 1. Specifications of CPV/T.

\begin{tabular}{ll}
\hline General Specifications & Solarus \\
Brand & $65 \mathrm{KG}$ \\
Weight & $2.31 \mathrm{~m}^{2}$ \\
Aperture area & $2.57 \mathrm{~m}^{2}$ \\
Gross area & super transparent \\
Optical transmittance & \\
Thermal Specifications & $4.8 \mathrm{~W} / \mathrm{m}^{2}-\mathrm{K}$ \\
Heat loss coefficient & $1250 \mathrm{~W}$ \\
Peak power & $1,4 \mathrm{~L} / \mathrm{modul}^{\circ}$ \\
Capacity antifreeze & $10 \mathrm{bar}$ \\
Max working pressure & $180{ }^{\circ} \mathrm{C}$ \\
Stagnation temperature & \\
Electrical Specifications & 152 \\
Number of cells & $52 \times 156 \times 0,2 \mathrm{~mm}$ \\
Cell dimension & $250 \mathrm{~W}_{\mathrm{p}} \pm 5 \%$ \\
Peak electrical power & \\
STC: $1000 \mathrm{~W} / \mathrm{m}^{2}-25^{\circ} \mathrm{C}$ &
\end{tabular}


Table 2. Specifications of Online Grid Hybrid Inverter.

\begin{tabular}{ll}
\hline General Specifications & SUMRY \\
Brand & PS 3KVA \\
Model Name & $0-55^{\circ} \mathrm{C}$ \\
Operating Temperature Range & \\
Inverter Mode & $3000 \mathrm{VA} / 2400 \mathrm{~W}$ \\
Rated Power & $24 \mathrm{VDC}, 100 \mathrm{~A}$ \\
DC Input & $230 \mathrm{VA}, 50 \mathrm{~Hz}, 13 \mathrm{~A}, 1 \Phi$ \\
AC Output & \\
AC Charger Mode & $230 \mathrm{VAC}, 50 \mathrm{~Hz}, 17.7 \mathrm{~A}, 1 \Phi$ \\
AC Input & $27 \mathrm{VDC}, 30 \mathrm{~A} / 20 \mathrm{~A}$ \\
DC Output & $230 \mathrm{VAC}, 50 \mathrm{~Hz}, 13 \mathrm{~A}, 1 \Phi$ \\
AC Output & \\
Solar Charger Mode & $50 \mathrm{~A}$ \\
Rated Current & $24 \mathrm{VDC}$ \\
System Voltage & $80 \mathrm{VDC}$ \\
Max. Solar Voltage(VOC) &
\end{tabular}

\begin{tabular}{lll}
\hline & Table 3. Fan-coil properties. \\
\hline Brand & DAIKIN EUROPE \\
& NV & \\
Model Name & FWV03CCTN6V3 & \\
Power Input & $56 \mathrm{~W}$ & \\
Cooling capacity & Total capacity & $2.93 \mathrm{~kW}$ \\
& Sensible & $2.11 \mathrm{~kW}$ \\
Heating capacity & capacity & $3.81 \mathrm{~kW}$ \\
(2-pipe) & & $5041 / \mathrm{h}$ \\
Water flow & Cooling & $5041 / \mathrm{h}$ \\
Water pressure & Heating & $11 \mathrm{kPa}$ \\
drop & Cooling & $9 \mathrm{kPa}$ \\
Fan & Heating & Centrifugal multi-blade, \\
& Type & $442 \mathrm{~m}^{3} / \mathrm{h}$ \\
\hline
\end{tabular}

\section{Energy analysis}

Thermal energy gain in the system is determined as follows by measuring the inlet and outlet temperatures of the air passing through the fan-coil.

$\dot{Q}_{u}=\dot{m} c_{p}\left(T_{o}-T_{i}\right)$

Where $\dot{m}$ is the mass flow rate of the air circulated in the fancoil $(\mathrm{kg} / \mathrm{s}), c_{p}$ is the specific heat of the circulating air $(\mathrm{J} / \mathrm{kg}$ ${ }^{\circ} \mathrm{C}$ ) and $T_{o}$ and $T_{i}$ are the fan-coil inlet and outlet temperatures of the circulated air. The mass flow rate of the air circulating in the fan-coil was also calculated as follows.

$\dot{m}_{a}=\rho_{a} \times v_{a} \times A$

Where $\rho_{a}$ is the density of the air $\left(\mathrm{kg} / \mathrm{m}^{3}\right), v_{a}$ the speed of air evacuating from the fan-coil $(\mathrm{m} / \mathrm{s})$ and $A$ represents the cross-sectional area of the fan-coil outlet duct $\left(\mathrm{m}^{2}\right)$.

$\mathrm{CPV} / \mathrm{T}$ panels connected in parallel to each other in the system are connected to a $3 \mathrm{KVA}$ online grid hybrid inverter and the electrical energy gain acquired from the panels with the current-voltage values read from the inverter is calculated with the following equation.

$\dot{E}_{n e t}=V_{o c} \times I_{s c}$

Where $V_{o c}$ is the open-circuit voltage generated by panels connected in parallel and $I_{s c}$ is short circuit current. The total useful thermal energy obtained from the system can be calculated as follows.

$\dot{Q}_{u, \text { overall }}=\dot{Q}_{u}+\frac{\dot{E}_{\text {net }}}{C_{\text {power }}}$

In the equation, $C_{\text {power }}$ is used to convert electrical energy gain to thermal energy recovery. $C_{\text {power }}$ is a thermal power plant coefficient that converts heat energy into electrical energy depending on the quality of the coal. $C_{\text {power }}$ can be considered as 0.38 for a quality coal with low ash content. This value is between 0.20 and $0.40 . \dot{E}_{n e t}$ is the total electrical power obtained by the system [11].

The total thermal energy efficiency of the system can be calculated as follows. Where $A_{\text {panel }}$ is the total area of the two $\mathrm{CPV} / \mathrm{T}$ panels used, $I_{(t)}$ is the total radiation across the panel surface, C.F. is the concentration factor, $W_{\text {fan-coil }}+$ $W_{\text {pump }}$ is the energy consumed by the fan-coil and pump used in the system.

$\eta_{\text {overall }(\text { thermal })}=\frac{\dot{Q}_{u, \text { overall }}}{A_{\text {panel }} \times I_{(t)} \times C . F .+\left(W_{\text {fan-coil }}+W_{\text {pump }}\right)}$

Concentration factor can be calculated as follows. Where $\theta_{c}$ is Reflector's acceptance angle $\left(90^{\circ}\right)$ [14]

$C . F .=\frac{1}{\sin \left(\theta_{c} / 2\right)}$

Concentrated solar radiation can be calculated as follows. Where $I_{(t)}$ is the total radiation across the panel surface, C.F. is the concentration factor [17].

Concentrated solar radiation $=$ C. F. $\times I_{(t)}$

The total electrical energy efficiency of the system can be calculated as follows [10].

$\eta_{\text {overall }(\text { electrical })}=\frac{\dot{E}_{\text {net }}}{A_{\text {panel }} \times I_{(t)} \times C . F .+\left(W_{\text {fan-coil }}+W_{\text {pump }}\right)}$

\section{Uncertainty analysis}

An uncertainty analysis was performed to assign reliable limits to the accuracy of the recorded values. The following equations were used to calculate uncertainty.

$X_{m}=\frac{1}{N} \sum X_{i}$

$V=\frac{1}{(N-1)} \sum\left(X_{i}^{2}-X_{m}^{2}\right)$

$S=\sqrt{V}$

$a=\frac{1}{\sqrt{N}}$

$U=\sqrt{\sum_{i=1}^{R} a_{i}^{2}} \cdot S_{i}^{2}$

Where $X_{m}$ is the arithmetic mean of observations, $X_{i}$ is observations, $N$ is the number of observations, $a$ is precision, $S$ is the standard deviation, $V$ is variance and $U$ is uncertainty. Uncertainty analysis was made using Eq. (13) for measured values in the system and these values in shown Table 4 [18]. 
Table 4. Measurement devices and specifications.

\begin{tabular}{|c|c|c|c|c|}
\hline $\begin{array}{l}\text { Measurement } \\
\text { Point }\end{array}$ & $\begin{array}{l}\text { Measured } \\
\text { value }\end{array}$ & Name of the device & Device properties & Uncertainty \\
\hline 1 & $\begin{array}{l}\text { Solar } \\
\text { radiation }\end{array}$ & $\begin{array}{l}\text { Pyranometer (EKO Instruments, Model: MS- } \\
602 \text { ) }\end{array}$ & $\begin{array}{l}\text { Irradiance range: } 0-2000 \mathrm{~W} / \mathrm{m}^{2} \text {; Sensitivity: } \\
\text { Approx. } 7 \mu \mathrm{V} / \mathrm{W} / \mathrm{m}^{2} \text {; Non-linearity at } \\
1000 \mathrm{~W} / \mathrm{m}^{2}, \pm 1.5 \% \text {. }\end{array}$ & $\pm 9.73 \mathrm{~W} / \mathrm{m}^{2}$ \\
\hline $\begin{array}{l}\text { T1, T2, T3, T4, } \\
\text { T5, T6 }\end{array}$ & Temperature & Pico USB TC-08 data logger & $\begin{array}{l}\text { Temperature accuracy: Sum of } \pm 0.2 \% \text { of } \\
\text { reading and } \pm 0.5^{\circ} \mathrm{C} \text {. }\end{array}$ & $\pm 0.22{ }^{\circ} \mathrm{C}$ \\
\hline \multirow[t]{2}{*}{$\mathrm{T} 7$} & & Process control equipment & $\begin{array}{l}\text { ORDEL, PC } 440,4 \mathrm{~W}, 100-240 \mathrm{VAC}, \\
\text { transmitter supplement } 24 \mathrm{VDC} \text {, auto-tuning, } \\
\text { PID control. }\end{array}$ & $\pm 0.37{ }^{\circ} \mathrm{C}$ \\
\hline & & Inverter & $\begin{array}{l}\mathrm{ABB}, \mathrm{AC} \text { variable speed drive mono phase } \\
\text { induction motors } 0.75 \mathrm{~kW}(1 \mathrm{HP}) \text {. }\end{array}$ & - \\
\hline 4 & Air Speed & HoldPeak HP-846A Digital Anemometer & $\begin{array}{l}\text { Wing Speed Range: } 0.3-45 \mathrm{~m} / \mathrm{s} \text {, Wing Speed } \\
\text { Accuracy: } \pm 0.1 \operatorname{dgts}(\mathrm{m} / \mathrm{s})\end{array}$ & $\pm 0.08 \mathrm{~m} / \mathrm{s}$ \\
\hline 2 & $\begin{array}{l}\text { Voltage and } \\
\text { current }\end{array}$ & $\begin{array}{l}\text { Sumry } 3 \text { KVA } 2400 \text { Watt }+50 \text { A Online Grid } \\
\text { Hybrid Inverter }\end{array}$ & Efficiency: $98 \%$ & $\begin{array}{l}\text { For voltage } \\
\pm 0.13 \mathrm{~V}, \text { for } \\
\text { current } \pm 0.12 \\
\text { A }\end{array}$ \\
\hline 3 & $\begin{array}{l}\text { Fluid mass } \\
\text { flow rate }\end{array}$ & $\begin{array}{l}\text { Bass Instruments Inline Paddlewheel } \\
\text { Flowmeter }\end{array}$ & $\begin{array}{l}\text { Measuring Range: } 2.5 \ldots 421 / \mathrm{min} \text {, } \\
\text { Temperature: } 70^{\circ} \mathrm{C} \max \text {. Pressure: } 10 \text { bar } \\
\text { max. Accuracy: }< \pm 1 \% \text { F.S. }\end{array}$ & $\pm 0.07 \mathrm{l} / \mathrm{min}$ \\
\hline
\end{tabular}

Table 5. Thermophysical properties of $\mathrm{Al}_{2} \mathrm{O}_{3}$-water nanofluid and propylene glycol-water mix (obtained from suppliers).

\begin{tabular}{cccccc} 
& $\begin{array}{c}\text { Volume concentration } \\
\boldsymbol{\varphi}(\mathbf{\%})\end{array}$ & $\begin{array}{c}\text { Thermal conductivity } \\
\boldsymbol{k}(\mathbf{W} / \mathbf{m K})\end{array}$ & $\begin{array}{c}\text { Density } \\
\boldsymbol{\rho}\left(\mathbf{k g} / \mathbf{m}^{3}\right)\end{array}$ & $\begin{array}{c}\text { Heat capacity } \\
\boldsymbol{C}_{\boldsymbol{p}}(\mathbf{J} / \mathbf{k g K})\end{array}$ & $\begin{array}{c}\text { Viscosity } \\
\boldsymbol{\mu}(\mathbf{k g} / \mathbf{m s})\end{array}$ \\
$\begin{array}{c}\mathbf{A l}_{2} \mathbf{O}_{3} \text {-water } \\
\text { Propylene glycol- water }\end{array}$ & 0.5 & 0.62178 & 1010.82 & 4114.61 & 0.0008797 \\
\hline
\end{tabular}

\section{Results and discussion}

Each fluid was analyzed experimentally throughout different days. The solar radiation values for each day that of the experiment was carried out was measured and shown in Figure 4 (a). By substituting the measured solar radiation values for each day in Eq. (7), the concentrated solar radiation values were calculated and displayed in Figure 4 (b).
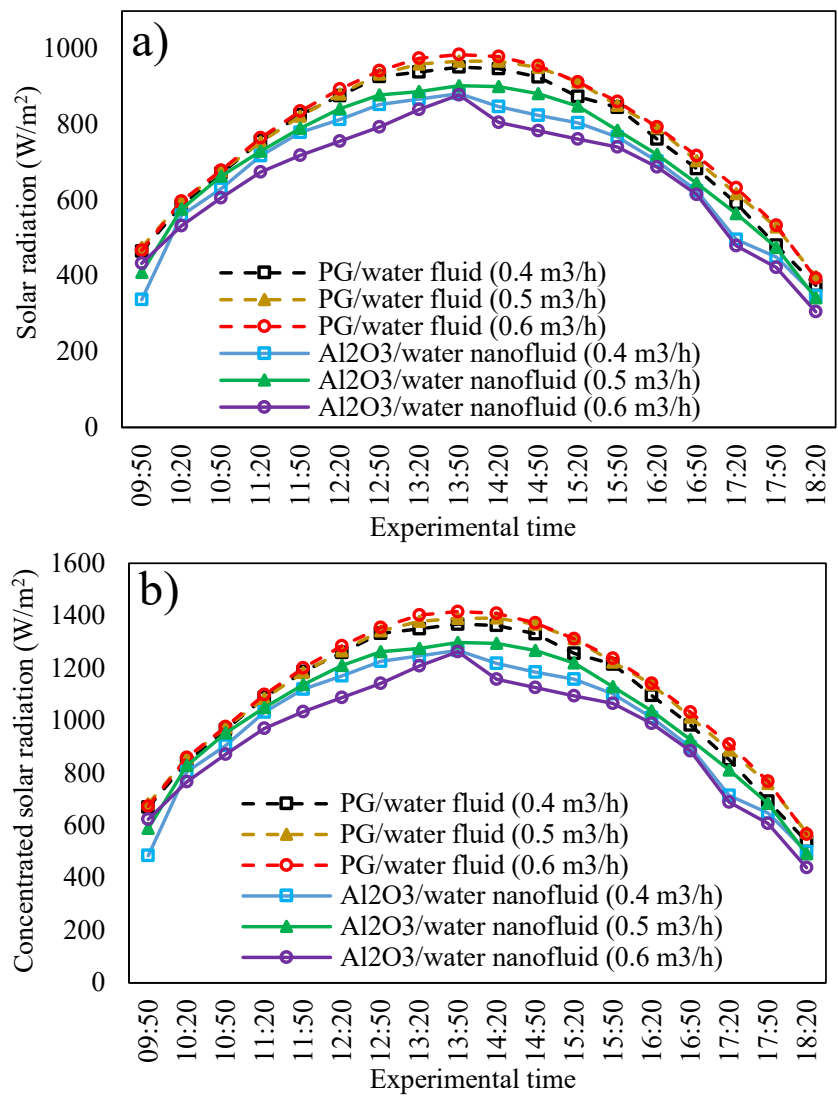

Figure 4. Solar radiation and concentrated solar radiation graphs according to experimental time.
Throughout the experiments, the fan-coil air outlet temperature was set to $35^{\circ} \mathrm{C}$ and the fan-coil air outlet temperatures were measured and given in Figure 5.

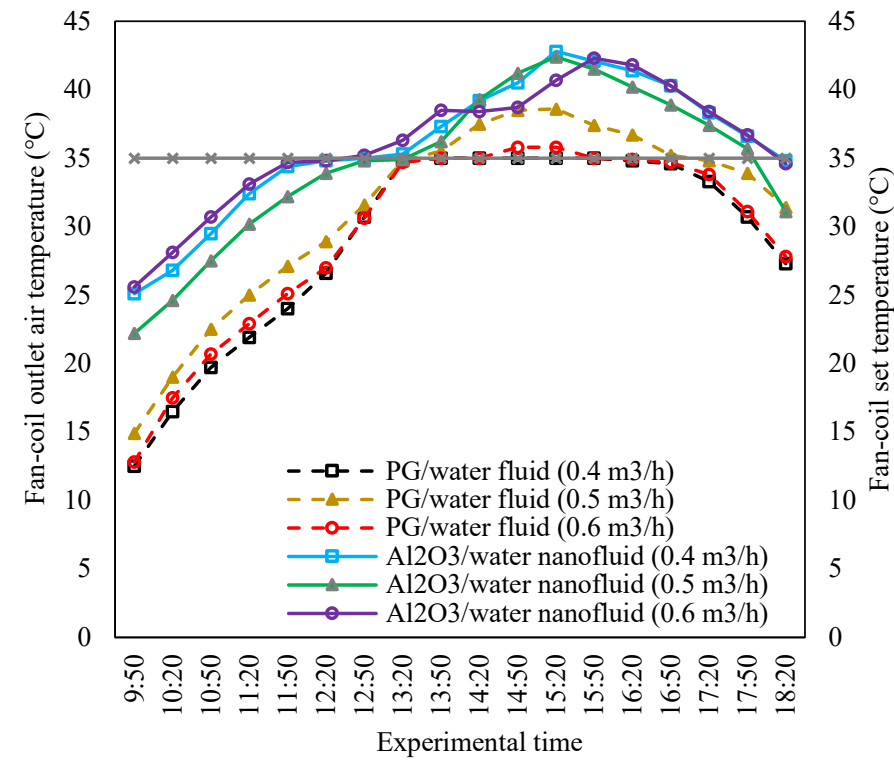

Figure 5. Fan-coil outlet air temperature and fan-coil set the temperature according to experimental time.

The solar radiation values measured in the experimental results belonging to both fluids are found to be almost the same. On the other hand, the time to reach the air temperature heated to the set temperature was reported to take a shorter time in the case of the nanofluid. It can therefore be said that the transient regime of the nanofluid does not last long. Plots illustrating a change in the temperature depending on the variable flow rates for PG/water fluid and for nanofluid are also given in Figure 6 a, b, c, and Figure 6 d, e, f, respectively. 

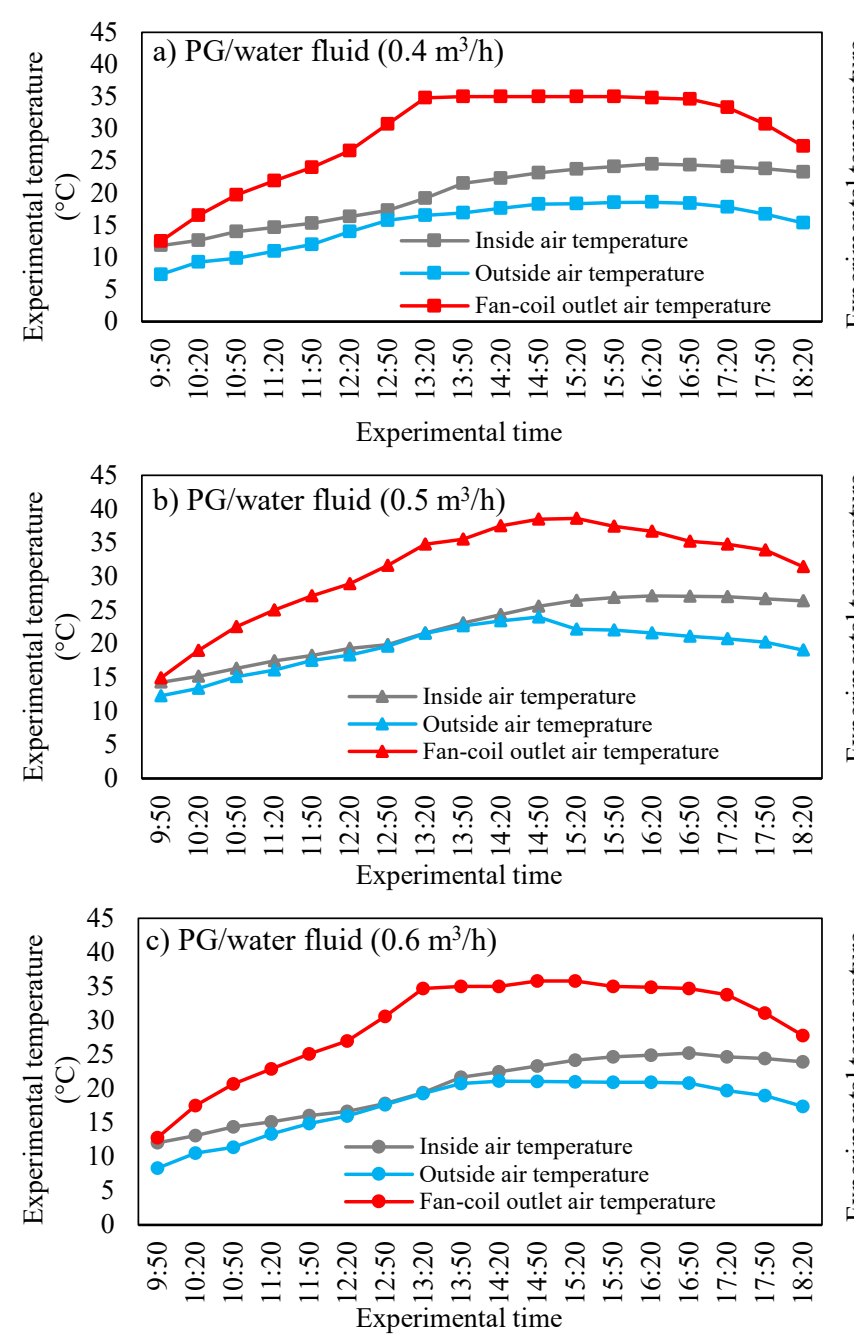

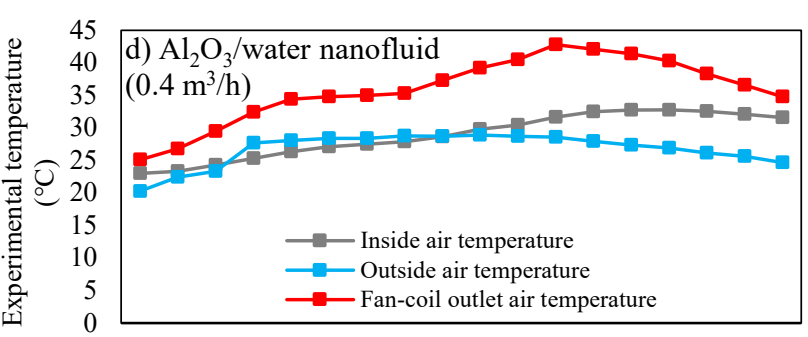

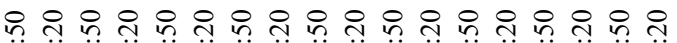

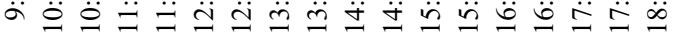
Experimental time

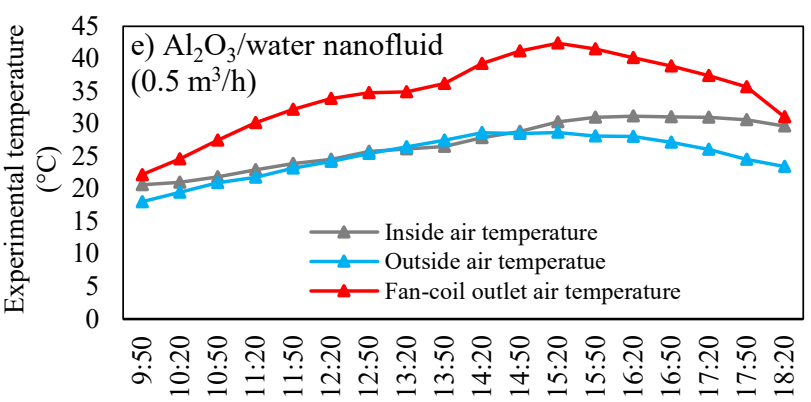

Experimental time

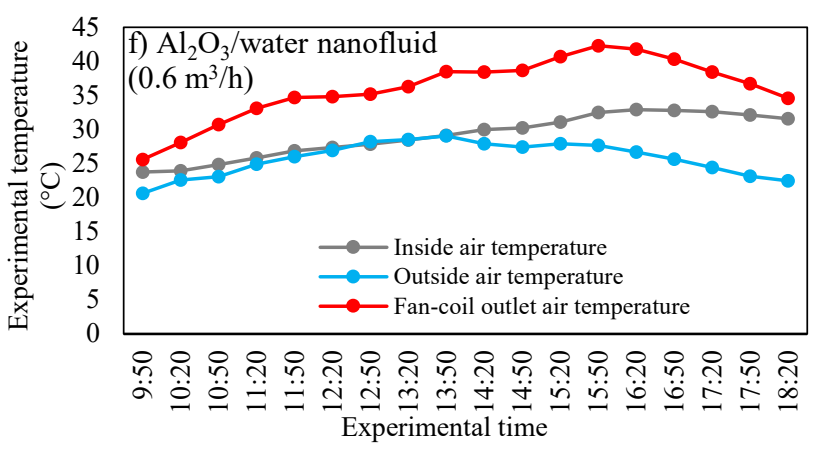

Figure 6. Shows plots of the change in the temperature depending on variable flow rates.

During the experiments, the average solar radiation incoming on the $\mathrm{CPV} / \mathrm{T}$ panels was measured as $1056 \mathrm{~W} / \mathrm{m}^{2}$. When the average solar irradiance is $1056 \mathrm{~W} / \mathrm{m}^{2}$ and the outdoor temperature ranges from 8 and $26^{\circ} \mathrm{C}$, the average outlet air temperature from the fan-coil is determined as 33 ${ }^{\circ} \mathrm{C}$. No significant difference was also observed in the increase of the average fan-coil outlet air temperature and the average room temperature at the different flow rates. The useful thermal energy in the system is calculated using Eq. (1), depending on the inlet and outlet temperatures of the air passing through the fan-coil in the system (Figure 7).

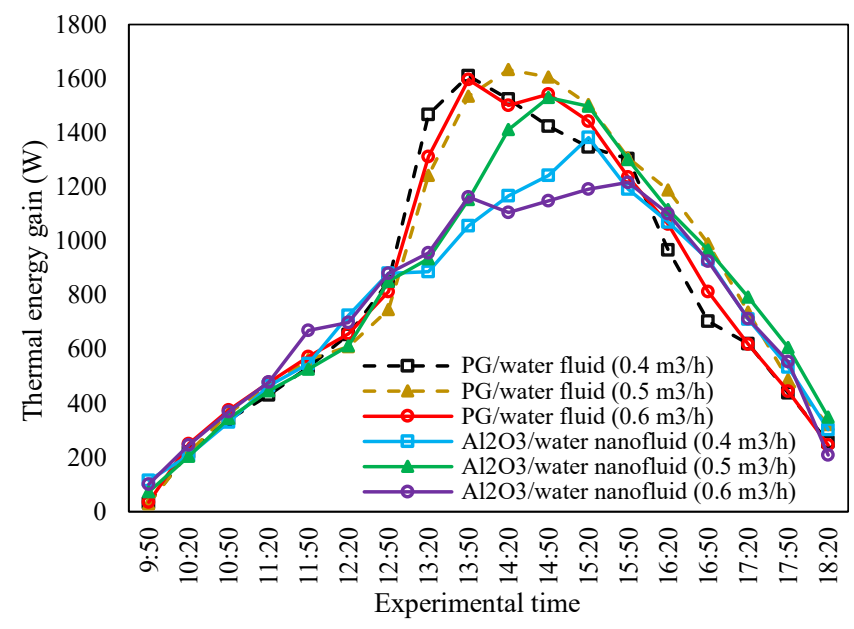

Figure 7. Thermal energy gain according to experimental time.
From Figure 7, it is seen that the highest useful thermal energy obtained from the system is $1632.86 \mathrm{~W}$ for $\mathrm{PG} /$ water mixture at $14: 20$ at $0.5 \mathrm{~m}^{3} / \mathrm{h}$ flow and $1529.86 \mathrm{~W}$ for $\mathrm{Al}_{2} \mathrm{O}_{3}$ water nano clean at $14: 50$ hours at $0.5 \mathrm{~m}^{3} / \mathrm{h}$. The useful thermal energy was reported to be higher for the $\mathrm{PG} /$ water mixture owing to the higher solar radiation during the days of the $\mathrm{PG} /$ water mixture in operation compared to nano mixture. It is also noteworthy that the fluids used in the system are taken into account within themselves at the different flow rates, they do not exhibit significant differences in terms of thermal energy gain. For the PG/water mixture where the most useful thermal energy is attained, the findings from the other experiments at the 14:20 and at the $0.5 \mathrm{~m}^{3} / \mathrm{h}$ flow rate are $1524.14 \mathrm{~W}$ for at the $0.4 \mathrm{~m}^{3} / \mathrm{h}$ flow rate and $1500.69 \mathrm{~W}$ at the $0.6 \mathrm{~m}^{3} / \mathrm{h}$ flow rate, respectively. The useful thermal energies acquired from the nanomixture at the same hour were $1167.52 \mathrm{~W}$ at the $0.4 \mathrm{~m}^{3} / \mathrm{h}$ flow rate, 1412.26 $\mathrm{W}$ at the $0.5 \mathrm{~m}^{3} / \mathrm{h}$ flow rate and $1105.43 \mathrm{~W}$ at the $0.6 \mathrm{~m}^{3} / \mathrm{h}$ flow rate, respectively. The useful electrical energy obtained from the panels was calculated using Eq. (3) and the total change in the useful electrical energy is also illustrated in Figure 8. 


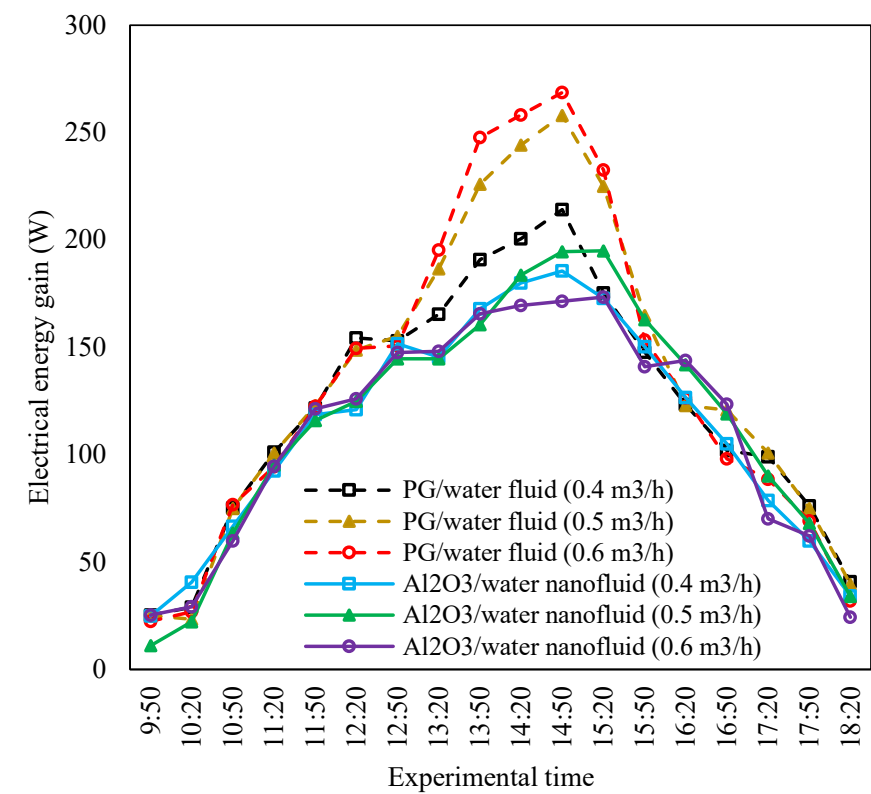

Figure 8. Electrical energy gain according to experimental time.

As can be seen in Figure 8, the higher useful electrical energy was attained from the nanomixture for $\mathrm{PG} /$ water mixture. It might be attributed to the higher radiation during the experimental days with the PG/water mixture. Besides, we can see from the plots that the useful electrical energy increases with the increase of radiation in both mixtures depending on the radiation. The total electrical energy efficiency of the system is calculated using Eq. (8) and is given in Figure 9. From the total electrical energy efficiency plot obtained from the system, it can be drawn that efficiency is not an accurate indicator for the electrical gain of systems using concentrators.

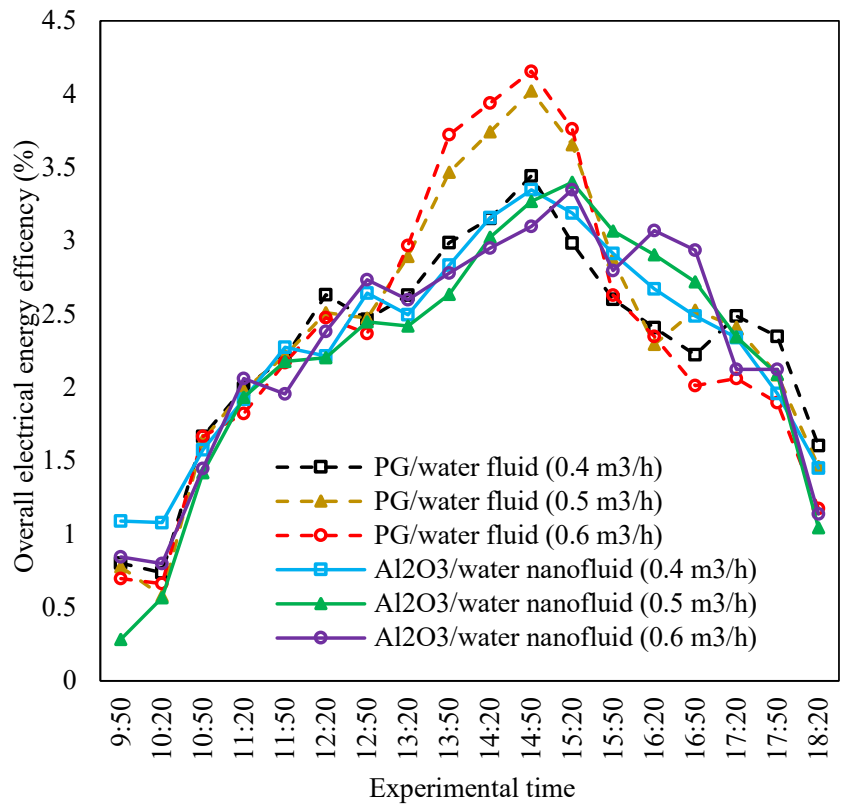

Figure 9. Overall electrical energy efficiency according to experimental time.

The useful thermal energy and electrical energy were collected, and the total useful thermal energy of the system was calculated using Eq. (4) and is given in Figure 10.

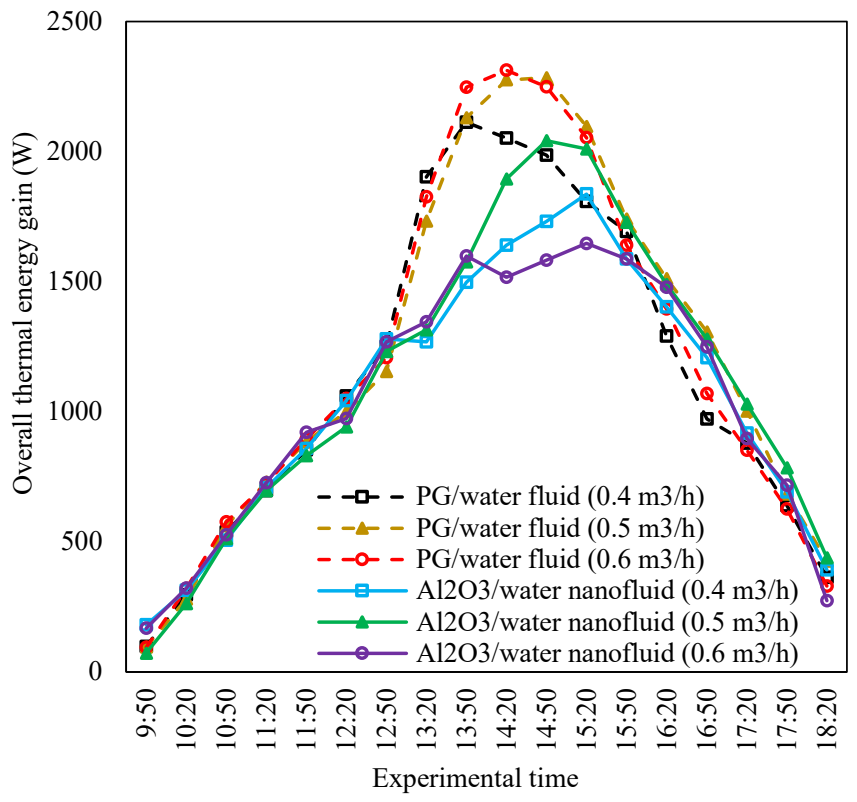

Figure 10. Overall thermal energy gain according to experimental time.

The highest total useful thermal energy obtained from the system by using different fluids is $2312.49 \mathrm{~W}$ at $14: 20$ for the $\mathrm{PG} /$ water mixture at the flow rate of $0.6 \mathrm{~m}^{3} / \mathrm{h}$ and 2041.86 $\mathrm{W}$ at $14: 50$ at the flow rate of $0.5 \mathrm{~m}^{3} / \mathrm{h}$ for the nanomixture. The total thermal energy efficiency of the system was calculated using Eq. (5) and the value obtained for both mixtures was approximately $22 \%$. The total thermal energy efficiency of the system is shown in Figure 11.

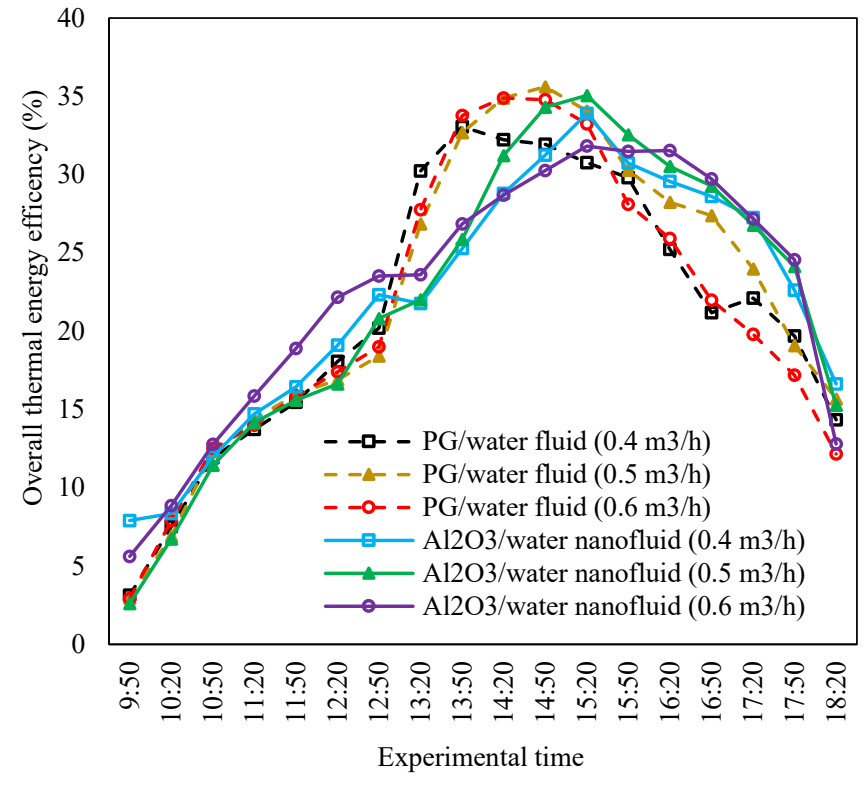

Figure 11. Overall thermal energy efficiency according to experimental time.

Changes in thermal energy gain (a), electrical energy gain (b), total electrical (c) and thermal energy efficiencies (d) depending on the concentrated solar radiation are given in Figure 12. 

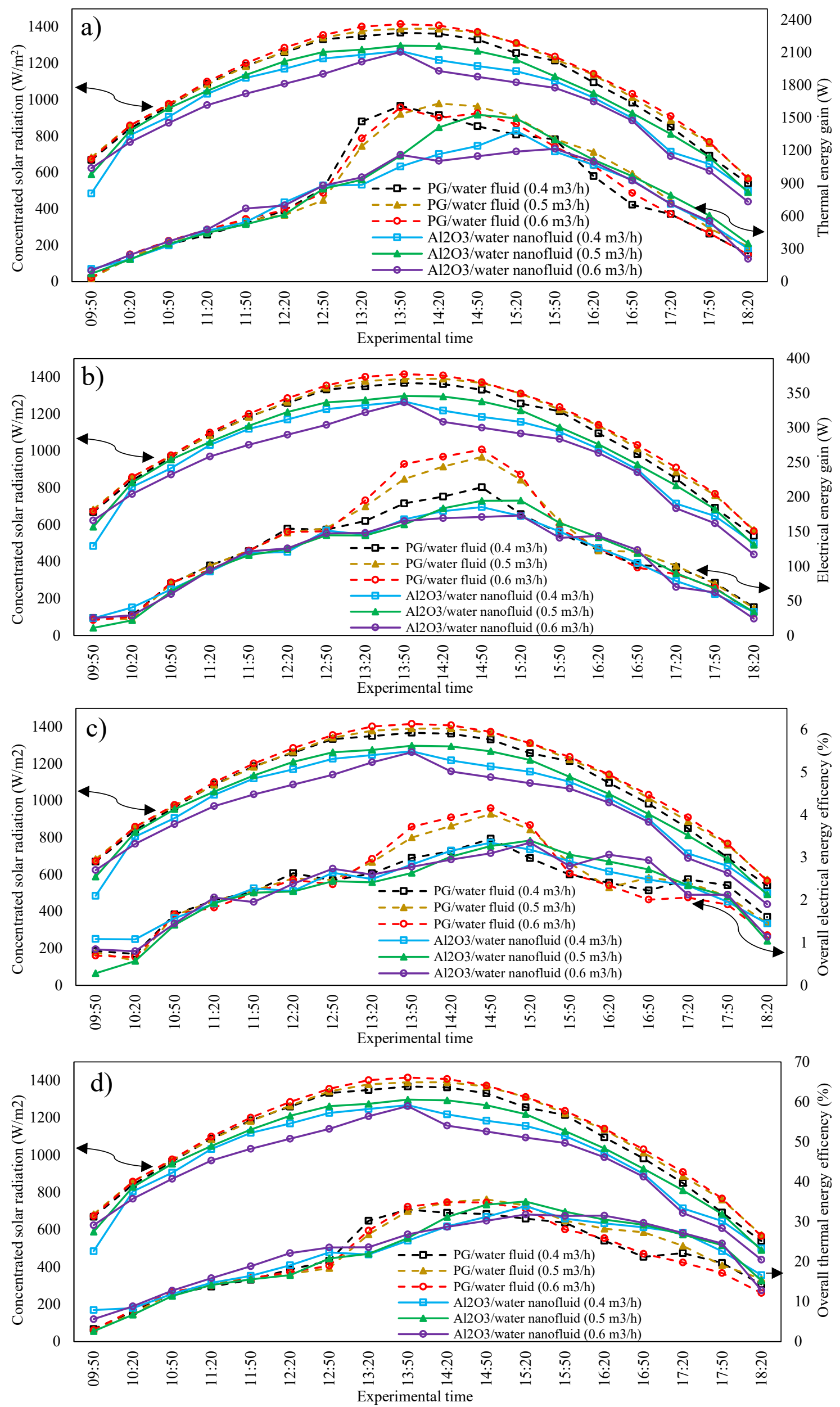

Figure 12. Electrical and thermal gain-efficiency graphs obtained from the system based on concentrated radiation. 
It is seen in Figure 12 (a) and (b) that the useful electrical and thermal energy increases for each fluid at different flow rates depending on the radiation. The highest useful electrical and thermal energies are accomplished between 13:00 and 15:00. As can be seen in Figure 12 (c) and (d), there is an increase in the electrical and thermal efficiencies with the increase of radiation, and the highest efficiency values were also achieved between 13:00 and 15:00.

\section{Conclusion}

Results and conclusions reported below by taking all data and calculations obtained from this work into account are as follows

- During the experiments, if the solar radiation incoming on the CPV/T panels was $730 \mathrm{~W} / \mathrm{m}^{2}$, the average concentrated solar radiation was calculated as 1056 $\mathrm{W} / \mathrm{m}^{2}$.

- The total thermal power obtained from the CPV/T panels was calculated as $1223.45 \mathrm{~W}$ for the $\mathrm{PG} /$ water mixture and $1096.42 \mathrm{~W}$ for the nanomixture and the average efficiency at those reported power values was found to be $22 \%$. This situation reveals that both fluids exhibit similar thermal properties.

- The highest electrical power obtained from CPV/T panels was measured as $268.65 \mathrm{~W}$ at $0.6 \mathrm{~m}^{3} / \mathrm{h}$ flow for PG/water mixture.

- Throughout the experiments, fan-coil air outlet temperatures were adjusted to $35^{\circ} \mathrm{C}$ through an inverter and process control equipment. The time to reach the desired fan-coil air outlet temperature does not take a long time for the nanomixture in comparison with the PG/water mixture.

- When the solar radiation across horizontal plane of the $\mathrm{CPV} / \mathrm{T}$ the is $1056 \mathrm{~W} / \mathrm{m}^{2}$ and the outdoor temperature ranges from $8{ }^{\circ} \mathrm{C}$ and $26{ }^{\circ} \mathrm{C}$, the fan-coil outlet air temperature is also determined as $33^{\circ} \mathrm{C}$. The change in the room temperature is found to alter in proportion to the change in the fan-coil outlet air temperature.

- It can be said that the installed experimental system can be used for space heating applications in cold weather in the region where applied.

$\begin{array}{ll}\text { Nomenclature } \\ \text { PV } & \text { Photovoltaic } \\ \text { CPV } & \text { Concentrated photovoltaic } \\ \text { PV/T } & \text { Photovoltaic thermal } \\ \text { CPV/T } & \text { Concentrated photovoltaic-thermal } \\ A & \text { Cross-sectional area }\left(\mathrm{m}^{2}\right) \\ \dot{m} & \text { Mass flow rate }(\mathrm{kg} / \mathrm{s}) \\ c_{p} & \text { Specific heat }\left(\mathrm{J} / \mathrm{kg}{ }^{\circ} \mathrm{C}\right) \\ I_{(t)} & \text { Incident total radiation }\left(\mathrm{W} / \mathrm{m}^{2}\right) \\ \dot{E}_{n e t} & \text { Rate of electrical energy }(\mathrm{W}) \\ \dot{Q}_{u} & \text { Rate of useful energy transfer }(\mathrm{W}) \\ V_{o c} & \text { Open circuit volt }(\mathrm{V}) \\ I_{s c} & \text { Short circuit current }(\mathrm{A}) \\ C_{p o w e r} & \text { Conversion power of the thermal power plant } \\ T & \text { Temperature }\left({ }^{\circ} \mathrm{C}\right)\end{array}$

\begin{tabular}{ll}
$v$ & Air velocity $(\mathrm{m} / \mathrm{s})$ \\
$\theta_{\mathrm{c}}$ & Reflector's acceptance angle $\left(^{\circ}\right)$ \\
\multicolumn{2}{l}{ Subscript } \\
$\mathrm{i}$ & inlet \\
o & outlet \\
a & air \\
Greek symbols \\
$\rho$ & density $\left(\mathrm{kg} / \mathrm{m}^{3}\right)$ \\
$\eta$ & efficiency
\end{tabular}

\section{References}

[1] S. Preet, "Water and phase change material based photovoltaic thermal management systems: a review", Renew. Sustain. Energy Rev., 82, 791-807, 2018.

[2] A. H. Kazem, "Evaluation and analysis of water-based photovoltaic/thermal (PV/T) system", Case Stud. Therm. Eng., 13, 100401, 2019.

[3] M. Hasanuzzaman, A.B.M.A. Malek, M.M. Islam, A.K. Pandey, N.A. Rahim, "Global advancement of cooling technologies for PV systems: a review”, Sol. Energy, 137, 25-45, 2016

[4] L. Hui, T.T. Chow, J. Ji, "Building-integrated heat pipe photovoltaic/thermal system for use in Hong Kong", Sol. Energy, 155, 1084-1091, 2017.

[5] M. Ghalandari, A. Maleki, A. Haghighi, M.S. Shadloo, M.A. Nazari, I. Tlili, "Applications of nanofluids containing carbon nanotubes in solar energy systems: A review", J. Mol. Liq., 313, 113476, 2020.

[6] A. Ergün, H. Eyinç, "Performance assessment of novel photovoltaic thermal system using nanoparticle in phase change material", Int. J. Numer. Method H., 29(4), 1490$1505,2019$.

[7] A. K. Surana, K. J. Samuel, S. Harshit, U. Kumar, R.T.K. Raj, "Numerical Investigation of Shell and Tube Heat Exchanger Using $\mathrm{Al}_{2} \mathrm{O}_{3}$ Nanofluid", Int. J. of Thermo., 20(1), 59-68, 2017.

[8] H. Olia, M. Torabi, M. Bahiraei, M.H. Ahmadi, M. Goodarzi, M.R. Safaei, "Application of Nanofluids in Thermal Performance Enhancement of Parabolic Trough Solar Collector: State-of-the-Art”, Appl. Sci. 9, 463, 2019.

[9] W.B. Youssef, T. Maatallah, C. Menezo, S.B. Nasrallah, "Modeling and optimization of a solar system based on concentrating photovoltaic/thermal collector", Sol. Energy, 170, 301-313, 2018.

[10] S. Zuhur, İ. Ceylan, A. Ergün, "Energy, exergy and environmental impact analysis of concentrated PV/cooling system in Turkey”, Sol. Energy, 180, 567-574, 2019.

[11] S. Zuhur, İ. Ceylan, "Energy, Exergy and Enviroeconomic (3E) analysis of concentrated PV and thermal system in the winter application", Energy Rep., 5, 262-270, 2019.

[12] P. Alves, P.F.J. Fernandes, N.P.J. Torres, C.J.P. Branco, C. Fernandes, J. Gomes, "From Sweden to Portugal: The effect of very distinct climate zones on energy efficiency of a concentrating photovoltaic/thermal system (CPV/T)", Sol. Energy, 188, 96-110, 2019.

[13] E. Bellos, C. Tzivanidis, "Investigation of a nanofluidbased concentrating thermal photovoltaic with a parabolic reflector", Energy Convers. Manag., 180, 171-182, 2019.

[14] P.I. Koronaki, T.M. Nitsas, "Experimental and theoretical performance investigation of asymmetric 
photovoltaic/thermal hybrid solar collectors connected in series", Renew. Energy, 118, 654-672, 2018.

[15] M. M. Sarafraz, M. R. Safaei, A.S. Leon, I. Tlili, T. A. Alkanhal, Z. Tian, M. Goodarzi, M. Arjomandi, "Experimental Investigation on Thermal Performance of a PV/T-PCM (Photovoltaic/Thermal) System Cooling with a PCM and Nanofluid”, Energies, 12, 2572, 2019.

[16] Karabük İl Kültür ve Turizm Müdürlüğü, 2021. [Online]. Available: https://karabuk.ktb.gov.tr/TR63702/cografya.html. (Accessed: 29-March-2021).

[17] İ. Ceylan, A. E. Gürel, "Güneş Enerjisi Sistemleri ve Tasarımı”, 2. Baskı, Dora Basımevi, 2018.

[18] M. Kaya, A.E. Gürel, Ü. Ağbulut, İ. Ceylan, S. Çelik, A. Ergün, B. Acar, "Performance analysis of using $\mathrm{CuO}$ Methanol nanofluid in a hybrid system with concentrated air collector and vacuum tube heat pipe", Energy Convers. Manag., 199, 111936, 2019. 